\title{
The ReLATIONSHIP BETWEen MHC-DRB1 GeNe SECOND EXON POLYMORPHISM AND hydAtidosis Resistance OF ChInese Merino (Sinkiang JUnKen tYPe), KaZAKH AND DUOLANG SHEEP
}

\author{
LI R.Y.*, HUI W.Q.*, JIA B.*, SHI G.Q.*, ZHAO Z.S.*, SHEN H.*, PENG Q.*, LV L.M.*, ZHOU Q.W.* \& LI H.T.*
}

\section{Summary:}

The present study aimed at detecting the association of ovine major histocompatibility complex class II (Ovar II) DRB1 gene second exon and susceptibility or resistance to hydatidosis in three sheep breeds of Sinkiang. The MHC-DRB1 second exon was amplified by polymerase chain reaction (PCR) from DNA samples of healthy sheep and sheep with hydatidosis. PCR products were characterized by the restriction fragment length polymorphism (RFLP) technique. Five restriction enzymes, Mval, Haell, Sacl, Sacll, Hin1l, were used, yielding 14 alleles and 31 restriction patterns. Frequencies of patterns Mvalbc, Hin1lab, Sacllab, Haelllde, Haelldf, Haelldd $(P<$ $0.01)$ in Kazakh sheep, Saclab $(P<0.05)$ in Duolang sheep, and Haelllab, Haellce, Haelllde, Haellee $(P<0.01)$ in Chinese Merino (Sinkiang Junken type) sheep, were significantly higher in healthy sheep compared with infected sheep. These results indicated a strong association between these patterns and hydatidosis resistance. In contrast, the frequencies of Mvalbb, Sacllaa, Hin 1 lbb, Haelllef $(P<0.01)$ and Haelllab $(P<0.05)$ in Kazakh sheep, Saclbb, Haellae, Hin1lab $(P<0.05)$, Haelllaa, Haelllbe, Haelllef $(P<$ $0.01)$ in Duolang sheep, Sacllaa $(P<0.05)$ and Haelllbd, Hin $1 \mathrm{lbb}$, Haelllcf, Haelllef $(P<0.01)$ in Chinese Merino sheep (Sinkiang Junken type) were significantly lower in healthy sheep compared with infected sheep. This indicated a strong association between these patterns and hydatidosis susceptibility. In addition, sheep with the pattern of Haelllef demonstrated a high hydatidosis susceptibility $(P<0.01)$ in all three breeds, while sheep with the pattern Haellde demonstrated significant hydatidosis resistance $(P<0.01)$ in Kazakh and Chinese Merino sheep (Sinkiang Junken type). These results suggest that the Ovar-DRB1 gene plays a role in resistance to hydatidosis infection in the three sheep breeds.

KEY WORDS: Chinese merino sheep (Sinkiang Junken type), Kazakh sheep, Duolang sheep, Ovar-DRB1 exon 2, PCR-RFLP, hydatidosis.
Résumé : AsSOCIATIONS ENTRE LE DEUXIÈME EXON DU GÈNE DRB1 ET LA RÉSISTANCE À L'ÉCHINOCOCCOSE CHEZ DES MOUTONS MÉRINOS DE Chine (type Sinkiang Junken), KaZAKH et Duolang

Le but de cette étude était de rechercher les associations éventuelles entre le deuxième exon du gène DRB1 du complexe majeur d'histocompatibilité de classe II (Ovar II) et la susceptibilité ou la résistance à l'échinococcose chez trois races de moutons au Sinkiang. Le deuxième exon a donc été amplifié par PCR à partir d'échantillons $d^{\prime} A D N$ de moutons sains ou infectés. Les produits de $P C R$ ont été caractérisés par la technique de polymorphisme de la longueur des fragments obtenus après digestion enzymatique. Cinq enzymes ont été utilisées: Mval, Haelll, Sacl, Sacll, Hin1l, produisant 31 profils de restriction correspondant à 14 allèles. Chez les moutons sains, la présence de certains profils est significativement plus élevée que chez les moutons infectés. I/ s'agit des profils Mvalbc, Hin1lab, Sacllab, Haelllde, Haellldf, Haellldd ( $\mathrm{P}<0,01)$ chez les moutons Kazakh, de Saclab $(\mathrm{P}<0,05)$ chez les moutons Duolang, et de Haelllab, Haelllce, Haelllde, Haelllee $(\mathrm{P}<0,01)$ chez les moutons mérinos chinois (type Sinkiang Junken). Ces résultats indiquent une forte association entre ces profils particuliers et la résistance à l'échinococcose. Au contraire, la fréquence d'autres profils est significativement plus faible chez les animaux non infectés. II s'agit de Mvalbb, Sacllaa, Hin 1 lbb, Haelllef $(\mathrm{P}<0,01)$ et Haelllab $(\mathrm{P}<0.05)$ chez les moutons Kazakh, Saclbb, Haelllae, Hin1lab ( $<$ 0.05); Haelllaa, Haelllbe, Haelllef $(\mathrm{P}<0,01)$ chez les moutons Duolang, Sacllaa $(\mathrm{P}<0,05)$ et Haelllbd, Hin 1 lbb, Haelllcf, Haelllef $(\mathrm{P}<0,01)$ chez les moutons mérinos chinois (type Sinkiang Junken). Ceci indique une forte association de ces profils avec la susceptibilité à l'échinococcose. De plus, une susceptibilité très importante à l'échinococcose a été observée pour le profil Haelllef chez les toutes les races de moutons ( $\mathrm{P}<0,01)$, alors que le profil Haelllde est associé à une résistance significativement plus élevée $(\mathrm{P}<0,01)$ dans le cas des moutons Kazakh et des moutons mérinos chinois (type Sinkiang Junken). Ces résultats suggèrent que le gène Ovar-DRB1 joue un rôle dans la résistance à l'échinococcose chez les trois races de mouton.

MOTS-CLÉS : mouton mérinos chinois (type Sinkiang Junken), mouton Kazakh, mouton Duolang, Ovar-DRB1 exon 2, PCR-RFLP, hydatidose.

Andersen et al., 1997; Dalimi et al., 2002; Eckert \& Deplazes, 2004; Jenkins et al., 2005). Sinkiang Autonomous Region of China is a prevalent area of hydatidosis. In sheep, the overall prevalence rate for hydatidosis cysts is $38.89 \%$ to $61.25 \%$ (Li et al., 2005). Kazakh sheep and Duolang sheep, the local sheep of Sinkiang, are bred for meat and fat. Chinese Merino sheep (Sinkiang Junken type) produce excellent wool. In Sinkiang, hydatidosis in farm animals causes considerable economic problems due to the loss of meat and edible liver, as well as the value of the fleece from infected sheep. Therefore it also affects the life quality of herdsmen.

\footnotetext{
* College of Animal Science and Technology, Shihezi University, Shihezi, Sinkiang, 832003, P. R. China.

Correspondence: Bin Jia.

Tel: 869932058839

E-mail: 39473030@qq.com

Li R.Y. and Hui W.Q. contributed equally to this paper.
}

ydatidosis (Echinococcus granulosus) is recognized as one of the world major zoonoses, and is found all over the world (Rausch, 1995; 
In recent years, many animal breeding studies have focused on MHC genes as candidate genes for disease resistance and susceptibility. The MHC is a multigene family that controls immunological self/non-self recognition. They include genes for cell surface glycoproteins that present peptides of foreign and self proteins to $\mathrm{T}$ cells, thereby controlling both cell- and antibody-mediated immune responses (Klein, 1986). A striking characteristic of MHC genes is their extreme polymorphism.

Diversity driven by pathogens implies a strong association between MHC alleles and patterns of resistance to specific autoimmune or infectious diseases. Such a link was first shown for chickens, in which the B21 haplotype (MHC class IIB) confers the strongest resistance to the herpes virus responsible for Marek's disease (Briles et al., 1977; Longenecker \& Gallatin, 1978). Equally well known is the role of the chicken class I MHC in providing resistance to the Rous sarcoma virus (Schierman \& Collins, 1987; Kaufman \& Venugopal, 1998). The polymorphism of Ovar-DRB1 plays an important role in resistance to nematode infection in the Suffolk breed (Sayers et al., 2005).

MHC Class II Ovar-DRB1 was chosen as the immune response gene in this study because it is highly polymorphic, transcribed, and there are over 100 different $D R B 1$ alleles reported in Genbank based upon either restriction fragment length polymorphisms (RFLP) or the deduced amino acid sequence for the $\beta 1$ domain encoded by exon 2 (Dutia et al., 1994; Schwaigger et al., 1996; Jugo \& Vicario, 2001; Konnai et al., 2003; Herrmann et al., 2005). Others have shown specific MHC-DRB1 alleles associate with resistance and/or less severe clinical signs in human hydatidosis (Gottstein et al., 1996; Li et al., 2003). Konnai et al. (2003) detected the Ovar-DRB1 exon 2 polymorphisms of Suffolk sheep by polymerase chain reaction restriction fragment length polymorphism (PCR-RFLP).

In the present study, the polymorphism of the class II Ovar-DRB1 exon 2 was detected by PCR-RFLP analysis in three sheep breeds. We characterized the relationship between the Ovar- $D R B 1$ exon 2 polymorphism and hydatidosis resistance, and screened the genotypes associated with hydatidosis resistance and susceptibility in each sheep breed. Results of the present study may play an important role in developing new sheep breeds that are resistant to hydatidosis.

\section{MATERIALS AND METHODS}

\section{ANIMALS SAMPLING AND SAMPLE PREPARATION}

$\mathrm{B}$ lood samples of Chinese Merino sheep (Sinkiang Junken type; 604 healthy animals and 425 animals with hydatidosis) were donated by agricultural construction division 9 in Sinkiang. Blood samples of Duolang sheep (122 healthy sheep and 70 sheep with hydatidosis) were donated by agricultural construction division 3. Blood samples of Kazakh sheep ( 400 healthy sheep and 302 sheep with hydatidosis) were donated by agricultural construction division 4. The sheep with hydatidosis were distinguished from healthy sheep by a commercially available enzyme-linked immunosorbent assay (ELISA) kit (Shenzhen Combined Biotech Co., Ltd, Shanghai, China). Genomic DNA were obtained from whole blood by phenol-chloroform method (Liu et al., 1997), and stored in a $-20{ }^{\circ} \mathrm{C}$ freezer until analysis.

\section{DESIGN OF OVAR-DRB1 EXON 2-SPECIFIC PRIMERS AND PCR AMPLIFICATION}

The second exon of Ovar-DRB1 was amplified by PCR in two rounds. The first round of PCR was performed with primers OLA-ERB1 (5'-CCG GAA TTC CCG TCT CTG CAG CAC ATTTCT T-3') and HL031 (5'-TTT AAA TTC GCG CTC ACCTCG CCG CT-3') (adopted from Konnai et al., 2003). We subjected 100 ng of genomic DNA to PCR amplification in a total volume of $20 \mu \mathrm{l}$, containing $1.5 \mathrm{mM} \mathrm{MgCl}, 120 \mu \mathrm{M}$ dNTP, $0.2 \mathrm{mM}$ each primer, and $1.5 \mathrm{U}$ of Taq polymerase (TIANGEN Biological Engineering Technology And Service Company, Beijing, China). Reactions were performed in a thermocycler (Bio RAD, Germany) under the following conditions: a single cycle of $5 \mathrm{~min}$ at $94^{\circ} \mathrm{C}$, followed by 15 cycles of $94^{\circ} \mathrm{C}$ for $30 \mathrm{~s}, 50^{\circ} \mathrm{C}$ for $30 \mathrm{~s}$, and $72{ }^{\circ} \mathrm{C}$ for $60 \mathrm{~s}$, with a final extension at $72{ }^{\circ} \mathrm{C}$ for $10 \mathrm{~min}$. We used $3 \mu \mathrm{l}$ of the resulting mixture and primers OLAERB1and OLA-XRBI (5'-AGC TCG AGC GCT GCA CAG TGAAAC TC-3') (adopted from Konnai et al., 2003) for the second round of PCR. The cycling conditions for the second round were: a single cycle of $5 \mathrm{~min}$ at $94^{\circ} \mathrm{C}$, followed by 30 cycles of $94^{\circ} \mathrm{C}$ for $30 \mathrm{~s}, 63{ }^{\circ} \mathrm{C}$ for $30 \mathrm{~s}$, and $72{ }^{\circ} \mathrm{C}$ for $60 \mathrm{~s}$ with a final extension at $72{ }^{\circ} \mathrm{C}$ for $10 \mathrm{~min}$.

\section{POLYMORPHISM DETECTION BY RFLP}

PCR products $(10 \mu \mathrm{l})$ from the second round were digested for $4 \mathrm{~h}$ at $37^{\circ} \mathrm{C}$ with $5 \mathrm{U}$ of MvaI, HaeIII, SacI, SacII, or Hin1I (Shanghai Sangon Biological Engineering Technology And Service Co., Ltd., Shanghai, China) in a total volume of $20 \mu \mathrm{l}$. The products of enzyme digestion were analyzed by a $2.5 \%$ or $3 \%$ agarose gel electrophoresis.

\section{STATISTICAL ANALYSIS}

Hardy-Weinberg equilibrium of Ovar-DRB1 genotypes was analyzed by $\chi^{2}$ test. The distribution of genotypic frequency in healthy sheep and sheep with hydatidosis within a breed was analyzed by $\chi^{2}$ test. SPSS version 13.0 was used for statistical analysis. 


\begin{tabular}{llll}
\hline \multicolumn{1}{c}{ Restriction enzymes } & The genotypes of each restriction enzyme \\
\hline SacI & aa (296bp) & ab $(296 \mathrm{bp} / 208 \mathrm{bp} / 88 \mathrm{bp})$ & $\mathrm{bb}(208 \mathrm{bp} / 88 \mathrm{bp})$ \\
Hin $1 \mathrm{I}$ & aa $(296 \mathrm{bp})$ & $\mathrm{ab}(296 \mathrm{bp} / 178 \mathrm{bp} / 118 \mathrm{bp})$ & $\mathrm{bb}(178 \mathrm{bp} / 118 \mathrm{bp})$ \\
MvaI & $\mathrm{bb}(123 \mathrm{bp} / 87 \mathrm{bp} / 86 \mathrm{bp})$ & $\mathrm{bc}(210 \mathrm{bp} / 123 \mathrm{bp} / 87 \mathrm{bp} / 86 \mathrm{bp})$ & $\mathrm{cc}(210 \mathrm{bp} / 86 \mathrm{bp})$ \\
SacII & aa $(296 \mathrm{bp})$ & $\mathrm{ab}(296 \mathrm{bp} / 229 \mathrm{bp} / 69 \mathrm{bp})$ & $\mathrm{bb}(229 \mathrm{bp} / 69 \mathrm{bp})$ \\
\hline
\end{tabular}

Table I. - PCR-RFLP genotypes of the second exon of the MHC-DRB1 gene.

\begin{tabular}{llll}
\hline Genotypes & Restriction fragments (bp) & Genotypes & Restriction fragments (bp) \\
\hline HaeIII aa & $173 / 71 / 48 / 4$ & HaeII af & $173 / 159 / 71 / 52 / 48 / 14 / 4$ \\
HaeIII bb & $173 / 123$ & HaeII bd & $173 / 159 / 123 / 14$ \\
HaeII cc & $159 / 137$ & HaeII be & $173 / 159 / 123 / 71 / 66$ \\
HaeIII dd & $159 / 123 / 14$ & HaeII cd & $159 / 137 / 123 / 14$ \\
HaeIII ee & $159 / 71 / 66$ & HaeII ce & $159 / 137 / 71 / 66$ \\
HaeII ff & $159 / 71 / 52 / 14$ & HaeII cf & $159 / 137 / 71 / 52 / 14$ \\
HaeIII ab & $173 / 123 / 71 / 48 / 4$ & HaeII de & $159 / 123 / 71 / 66 / 14$ \\
HaeIII ac & $173 / 159 / 137 / 71 / 48 / 4$ & HaeII df & $159 / 123 / 71 / 52 / 14$ \\
HaeIII ad & $173 / 159 / 123 / 71 / 48 / 4$ & HaeII ef & $159 / 71 / 66 / 52 / 14$ \\
HaeeII ae & $173 / 159 / 71 / 66 / 48 / 4$ & & \\
\hline
\end{tabular}

Table II. - The genotypes of PCR-RFLP by restriction enzyme HaeIII in the second exon of the Ovar-DRB1 gene.

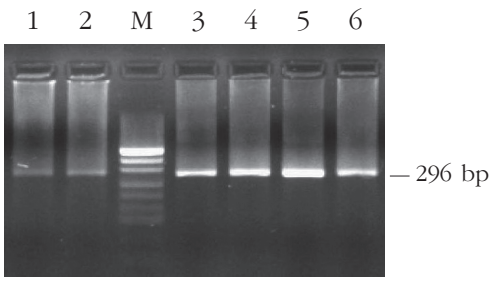

Fig 1 - Electrophoretic patterns of PCR product of the second exon of Ovar-DRB1 in Kazakh sheep, M: PUC19 DNA marker.

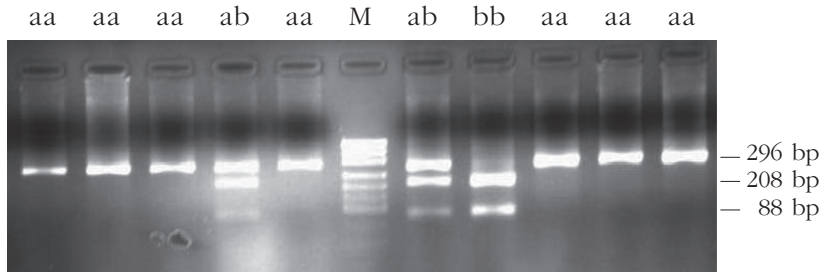

Fig 2 - Electrophoretic patterns of the second exon of Ovar-DRB1 digested with SacI in Kazakh sheep, M: puc19 DNA marker.

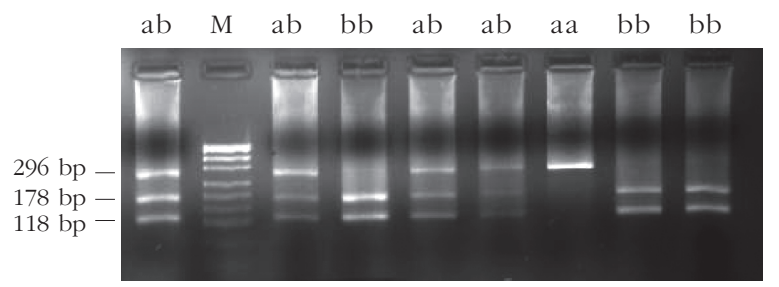

Fig 3 - Electrophoretic patterns of the second exon of Ovar-DRB1 digested with Hin1I in Kazakh sheep, M: puc19 DNA marker.

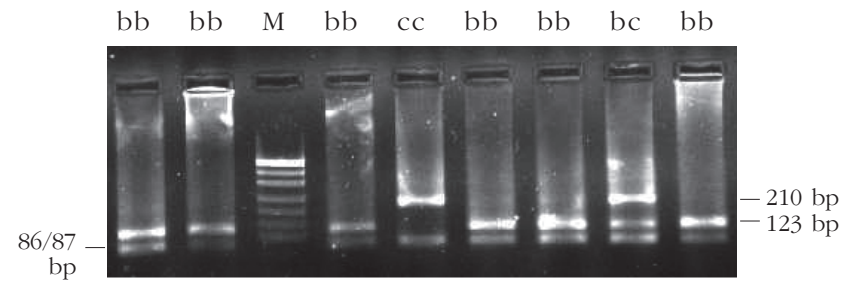

Fig 4 - Electrophoretic patterns of the second exon of Ovar-DRB1 digested with MvaI in Kazakh sheep, M: puc 19DNA marker.

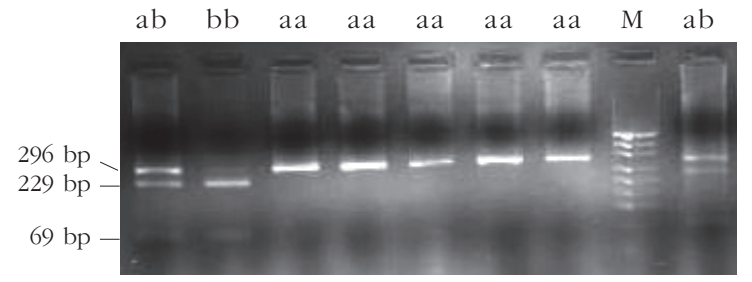

Fig 5 - Electrophoretic patterns of the second exon of Ovar-DRB1 digested with SacII in Kazakh sheep, M: puc19 DNA marker.

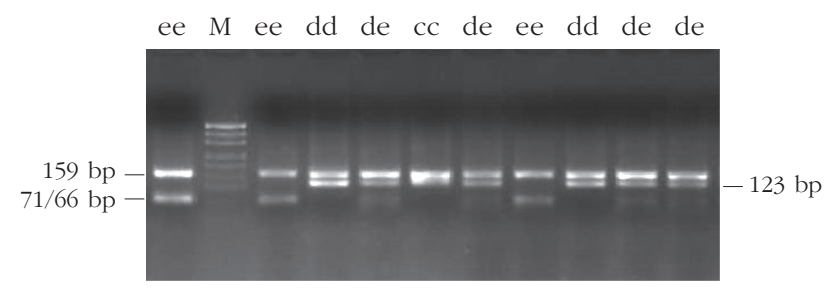

Fig 6 - Electrophoretic patterns of the second exon of Ovar-DRB1 digested with HaeIII in Kazakh sheep, M: puc19 DNA marker. 


\section{RESULTS}

\section{PCR AMPLIFICATION}

var- $D R B 1$ exon 2 was amplified by PCR with primers OLA-ERB1, OLA-HL031, and OLAXRBI. A 296-bp band corresponding to the expected size of exon 2 was observed by $1.5 \%$ agarose gel electrophoresis (Fig. 1).

\section{PCR-RFLP}

Restriction enzyme analysis with SacI, Hin1I, MvaI, SacII and HaeIII produced restriction patterns and allele frequencies in accordance with that reported by Konnai et al. (2003). Restriction patterns are shown in Table I (SacI, Hin1I, MvaI, SacII) and Table II (HaeIII); fragments the genotypic restriction map is shown in Figs 2-6; and a diagram of this exonic region, the cleavage sites is shown in Fig. 7. The Ovar-DRB1 exon 2 of Chinese Merino, Duolang and Kazakh sheep was analyzed by PCR-RFLP using restriction enzymes SacII (two alleles, three genotypes), MvaI (two alleles, three genotypes), SacI (two alleles, three genotypes), Hin1I (two alleles, three genotypes), and HaeIII (six restriction profiles, 19 patterns). Polymorphisms were detected at base pairs 229, 225, 208, 210, 178, 173, $159,87$.

\section{CHI-SQUARE ANALYSIS}

The Ovar-DRB1 exon 2 alleles of three breeds were analyzed by $\chi^{2}$ test to determine whether they were consistent with the Hardy-Weinberg distribution, using data shown in Table 3. The $\chi^{2}$ value of the patterns in Kazakh sheep were 173.85 (MvaI; 2 degrees of freedom [df]; $P<0.01$ ), 9.24 (SacI; 2 df; $P<0.01$ ), 0.33 (SacII; 2 df; $P>0.05$ ), and 5.84 (Hin1I; 2 df; $P>$ $0.05)$. These results indicated that patterns produced with restriction enzymes SacII and Hin1I were in Hardy-Weinberg equilibrium, while patterns produced by restriction enzymes $M v a \mathrm{I}$ and $S a c I$ were not.

The $\chi^{2}$ value of patterns in Duolang sheep were 1.25 (MvaI; $P>0.05$ ), 13.63 (SacI; $P<0.01$ ), 7.44 (SacII; $P<0.05$ ), and 16.11 (Hin1I; $P<0.01$ ). These results suggested that patterns produced by MvaI were in Hardy-Weinberg equilibrium, while patterns produced by SacI, SacII and Hin1I were not.

The $\chi^{2}$ value of patterns in Chinese Merino sheep were 0.03 (MvaI; P> 0.05), 1.62 (SacI; P> 0.05), 0.38 (SacII;
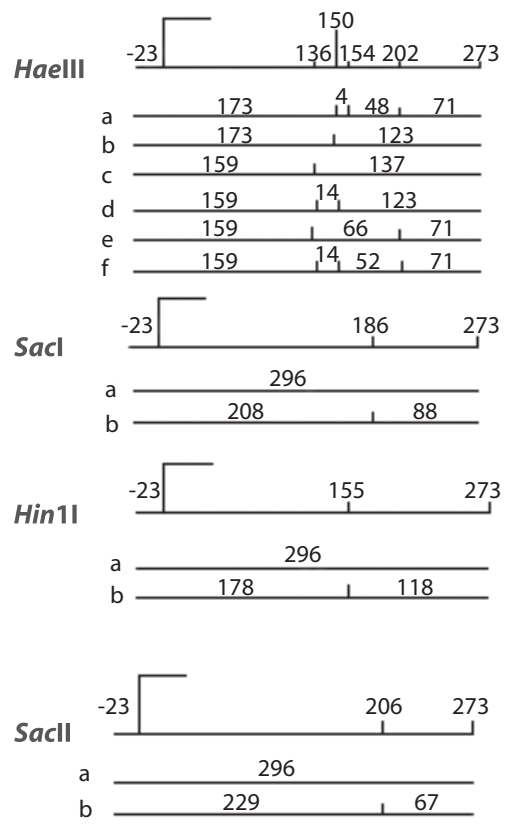

Mval
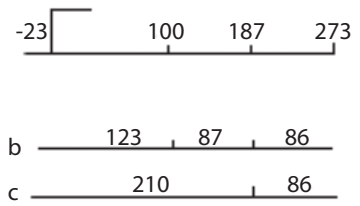
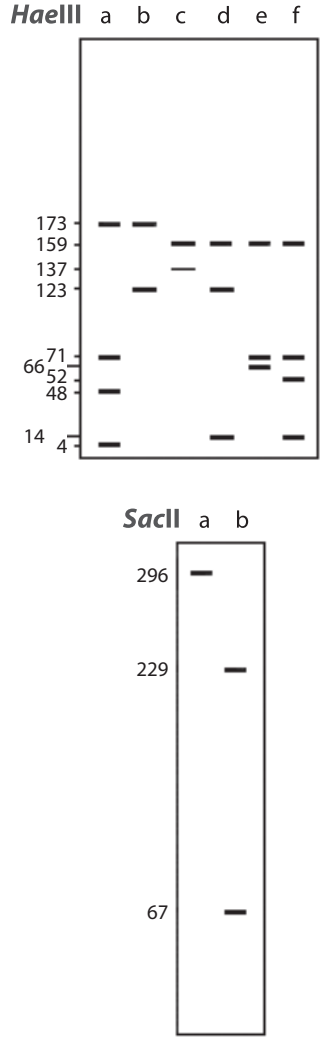
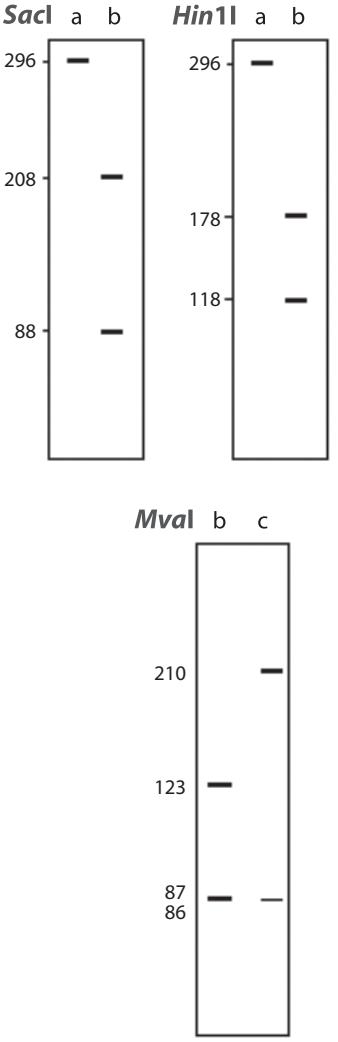

Fig 7 - The diagram of the cleavage sites and fragments in MHC-DRB1 second exon. 
$P>0.05)$, and 2.14 (Hin $1 \mathrm{I} ; P>0.05)$. These results suggested that patterns produced by MvaI, SacI, SacII, and Hin1I were in Hardy-Weinberg equilibrium.

\section{RELATIONSHIP BETWEEN OVAR-DRB1 GENOTYPES AND HYDATIDOSIS RESISTANCE}

Comparison of genotypes in sheep with hydatidosis and healthy controls is shown in Table III. Analysis revealed a higher frequency of patterns MvaIbc, Hin1Iab, SacIIab, HaeIIIde, HaeIIIdf, and HaeIIIdd $(P<0.01)$ in Kazakh sheep, SacIab $(P<0.05)$ in Duolang sheep, and HaeIIIab, HaeIIIce, HaeIIIde, and HaeIIIee $(P<0.01)$ in Chinese Merino sheep (Sinkiang Junken type) in healthy sheep compared with infected sheep, indicating a strong association between these patterns and hydatidosis resistance. Frequencies of patterns MvaIbb, SacIIaa, Hin1Ibb, HaeIIIef $(P<0.01)$ and HaelIIab $(P<0.05)$ in Kazakh sheep, SacIbb, HaeIIIae, Hin1Iab $(P<0.05)$ and HaeIIIaa, HaeIIIbe, HaeIIIef $(P<0.01)$ in Duolang sheep, SacIIaa $(P<$ $0.05)$ and HaeIIIbd, Hin1Ibb, HaeIIIcf, HaeIIIef $(P<$ 0.01) in Chinese Merino sheep (Sinkiang Junken type) were lower in healthy sheep compared with infected sheep, indicating a strong association between these patterns and hydatidosis susceptibility.

\section{DISCUSSION AND CONCLUSION}

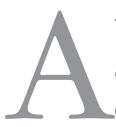
$\mathrm{t}$ present, both domestic and international studies have indicated that MHC genes show extensive polymorphism in humans, mice, cattle (Blattman et al., 1993; Xu et al., 1993), sheep, goats (Amills \& Francino, 1995, 1996; Yang et al., 2006;

\begin{tabular}{|c|c|c|c|c|c|c|}
\hline \multirow[b]{2}{*}{ Genotypes } & \multicolumn{2}{|c|}{$\begin{array}{l}\text { Chinese Merino sheep } \\
\text { (Sinkiang Junken type) }\end{array}$} & \multicolumn{2}{|c|}{ Kazakh sheep } & \multicolumn{2}{|c|}{ Duolang sheep } \\
\hline & Controls & $\begin{array}{l}\text { Hydatidosis } \\
\text { Sheep }\end{array}$ & Controls & $\begin{array}{l}\text { Hydatidosis } \\
\text { Sheep }\end{array}$ & Controls & $\begin{array}{l}\text { Hydatidosis } \\
\text { Sheep }\end{array}$ \\
\hline MvaIbb & $0.668(392)$ & $0.650(262)$ & $0.623(246)$ & $0.798^{* *}(241)$ & $0.569(62)$ & $0.593(32)$ \\
\hline MvaIbc & $0.291(171)$ & $0.325(131)$ & $0.377^{* *}(149)$ & $0.199(60)$ & 0.349 (38) & 0.333 (18) \\
\hline MvaIcc & $0.041(24)$ & $0.025(10)$ & $0(0)$ & 0.003 & $0.083(9)$ & $0.074(4)$ \\
\hline SacIaa & $0.472(262)$ & $0.495(207)$ & 0.546 (219) & $0.481(142)$ & 0.312 & 0.386 \\
\hline SacIab & $0.452(251)$ & $0.416(174)$ & $0.354(142)$ & 0.390 & $0.648^{*}(79)$ & $0.486(34)$ \\
\hline SacIbb & $0.076(42)$ & $0.089(37)$ & $0.100(40)$ & $0.129(38)$ & $0.041(5)$ & $0.128 *(9)$ \\
\hline SacIIaa & $0.612(322)$ & $0.686^{* *}(277)$ & $0.704(285)$ & $0.805^{* *}(243)$ & $0.500(43)$ & $0.444(20)$ \\
\hline SacIIab & 0.338 (178) & 0.280 & $0.277^{* *}(112)$ & $0.185(56)$ & 0.454 (39) & 0.511 \\
\hline SacIIbb & 0.049 (26) & 0.035 (14) & $0.020(8)$ & 0.010 & 0.047 (4) & 0.045 (2) \\
\hline Hin1Iaa & $0.224(124)$ & $0.195(82)$ & $0.355(142)$ & 0.361 (109) & 0.107 (13) & 0.029 (2) \\
\hline Hin1Iab & $0.495(274)$ & $0.441(185)$ & $0.498^{* *}(199)$ & $0.371(112)$ & $0.549(67)$ & $0.714 *(50)$ \\
\hline Hin $1 \mathrm{Ibb}$ & $0.282(156)$ & $0.364^{* *}(153)$ & 0.148 (59) & $0.268^{* *}(81)$ & $0.344(42)$ & 0.257 (18) \\
\hline HaeIIIaa & $0.092(50)$ & $0.090(38)$ & $0.024(10)$ & $0.049(15)$ & $0.041(5)$ & $0.129^{* *}(9)$ \\
\hline HaeIIIab & $0.059^{* * *}(32)$ & $0.017(7)$ & 0.009 (4) & $0.030^{*}(9)$ & $0.123(15)$ & $0.071(5)$ \\
\hline HaeIIIac & 0.024 & $0.040(17)$ & $0.007(3)$ & 0.010 & $0.033(4)$ & $0.043(3)$ \\
\hline HaeIIIad & $0(0)$ & 0.002 (1) & 0.007 & 0.007 (2) & 0.008 (1) & $0(0)$ \\
\hline HaelIIae & $0.037(20)$ & $0.050(21)$ & $0.034(14)$ & 0.040 & $0(0)$ & $0.057^{* * *}(4)$ \\
\hline HaeIIIaf & $0.009(5)$ & $0.019(8)$ & $0.010(4)$ & 0.013 (4) & 0.049 (6) & 0.028 \\
\hline HaeIIIbb & $0.037(20)$ & $0.019(8)$ & $0(0)$ & $0(0)$ & $0.033(4)$ & $0(0)$ \\
\hline HaeIIIbd & 0.004 (2) & $0.021^{* *}$ (9) & $0(0)$ & $0(0)$ & 0.025 (3) & $0(0)$ \\
\hline HaelIIbe & $0.004(2)$ & $0.012(5)$ & $0(0)$ & $0(0)$ & 0.008 (1) & $0.229^{* *}(16)$ \\
\hline HaeIIIcc & $0.092(50)$ & $0.126(53)$ & 0.092 (38) & $0.113(34)$ & $0.074(9)$ & 0.057 (4) \\
\hline HaeIIIcd & $0.013(7)$ & $0(0)$ & $0(0)$ & $0(0)$ & $0(0)$ & $0(0)$ \\
\hline HaeIIIce & $0.112^{* * *}(61)$ & $0.064(27)$ & $0.082(34)$ & $0.079(24)$ & 0.131 & $0.086(6)$ \\
\hline HaeIIIcf & $0.013(7)$ & $0.066^{* *}(28)$ & $0.034(14)$ & $0.013(4)$ & 0.098 (12) & 0.014 (1) \\
\hline HaeIIIdd & 0.029 (16) & $0.024(10)$ & $0.101^{* *}(42)$ & $0.036(11)$ & 0.008 (1) & $0(0)$ \\
\hline HaeIIIde & $0.099^{* *}(54)$ & $0.033(14)$ & $0.121^{* *}(50)$ & 0.030 & $0.041(5)$ & $0(0)$ \\
\hline HaeIIIdf & $0.037(20)$ & 0.042 (18) & $0.053(22)$ & $0.013(4)$ & $0.057(7)$ & 0.057 (4) \\
\hline HaellIee & $0.220^{\text {**** }}(120)$ & $0.149(63)$ & $0.253(105)$ & 0.318 & 0.148 (18) & $0.071(5)$ \\
\hline HaeIIIef & $0.073(40)$ & $0.173^{* *}(73)$ & $0.113(47)$ & $0.192^{* *}(58)$ & 0.008 (1) & $0.114^{* *}(8)$ \\
\hline HaeIIIff & $0.050(27)$ & $0.052(22)$ & $0.058(24)$ & 0.056 (16) & 0.115 (14) & $0.043(3)$ \\
\hline
\end{tabular}

The same genotypes in healthy group and hydatidosis group of one breed sheep, * $P<0.05, * * P<0.01$.

Table III. - Genotypic frequencies of the second exon of the MHC-DRB1 gene in healthy group and hydatidosis group of three breeds sheep. 
Sun et al., 2004), and chickens (Xu et al., 2005). Using PCR-RFLP, Yang et al. (2006) and Sun et al. (2004) investigated the MHC-DRB3 polymorphism in sheep and goats. Konnai et al. (2003) determined the Ovar$D R B 1$ exon 2 polymorphisms of 52 Suffolk sheep by PCR-RFLP with restriction enzymes SacI (two alleles), SacII (two alleles), Hin1I (two alleles), and HaeIII (six alleles), which was consistent with our results. Peng et al. (2007) determined Ovar-DRB1 exon 2 polymorphisms of 211 Chinese Merino sheep (Sinkiang Junken type) by PCR-RFLP with restriction enzymes SacI (two alleles, three genotypes) and Hin $1 \mathrm{I}$ (two alleles, three genotypes), which was also consistent with our results. However, six alleles and 15 patterns were found using the restriction enzyme HaeII in their study, while six alleles and 19 patterns were found using this enzyme in the present study. This difference may be due to different numbers and species of sheep. Last but not the least, the genotypes of HaeIII bc and bf weren't appearance in the population which we chosen. Perhaps they will be found in a larger population.

Ovar-DRB1 is a principal member of MHC class II DRB in sheep (Deverson et al., 1991; Scott et al., 1991; Ballingall et al., 1992). It is often used as a genetic marker in disease association studies (reviewed by Dukkipati et al., 2006). Azab et al. (2004) demonstrated that people who carry human leukocyte antigen (HLA)-DR3 and HLA-DR11 were at high risk for cystic echinococcosis (CE), and those with HLA-DR3 were more susceptible to complications. Shcherbakov \& Monje-Barredo (1989) showed that people with HLAB5 and B18 of HLA I antigen were at high risk for CE, while those with HLA-B14 and B27 had resistance to CE. In addition, Schwaiger et al. (1995) and Sayers et al., (2005) found that MHC-DRB1 was related to nematode resistance. Taken together, these results show that MHC polymorphisms are closely associated with parasite resistance or susceptibility. In the present study, the Ovar-DRB1 exon 2 polymorphisms in three breeds of sheep were also shown to be associated with hydatidosis resistance and susceptibility (Table III).

Analysis of the restriction patterns revealed that Chinese Merino sheep (Sinkiang Junken type), Duolang sheep, and Kazakh sheep with the pattern HaeIIIef all had high hydatidosis susceptibility. Chinese Merino (Sinkiang Junken type) and Kazakh sheep with the pattern HaeIIIde had strong hydatidosis resistance; in Duolang sheep, the HaeIIIde appeared to confer some hydatidosis resistance, but the association was not statistically significant. In addition, restriction analysis using enzyme HaeIII produced 19 patterns in Chinese Merino sheep (Sinkiang Junken type) in the present study; however, four of these patterns (HaeIIIbb, HaeIIIbd, HaeIIIbe, HaeIIIcd) were not detected in Kazakh sheep, and three of these patterns (HaeIIIcd,
HaeIIIad, HaeIIIae) were not detected in Duolang sheep. Kazakh sheep are the local sheep of Sinkiang Province. The Duolang sheep is a cross between Feitun sheep from Afghanistan and local sheep from Kashi City of Sinkiang (Jiang et al., 2006). The Chinese Merino sheep (Sinkiang Junken type) is a cross between a Merino ram from Australia and Sinkiang Junken sheep. The difference among the three breeds in HaeIII patterns of the Ovar-DRB1 second exon may be due to different breeding histories.

In the present research, we screened restriction patterns associated with hydatidosis resistance and susceptibility in three sheep breeds by PCR-RFLP. Additional research is needed to determine whether these patterns could serve as genetic markers for hydatidosis.

\section{ACKNOWLEDGEMENTS}

W e thank the people who provided samples from the regimental farms in Sinkiang. This study was supported by a grant from the Natural Science Foundation of China (30660124) to Prof. Bin Jia.

\section{REFERENCES}

Amills M. \& Francino O. Nest PCR allows the characterization of Taq I and Pst I RFLPs in the second exon of the Caprine MHC class II DRB gene. Veterinary Immunology and Immunopathology, 1995, 48, 313-321.

Amills M. \& FRANCINO O. A PCR-RFLP typing method for the Caprine MHC class II DRB gene.Veterinary Immunology and Immunopathology, 1996, 55, 255-260.

Andersen F.L., Ouhelli H. \& Kashani M. Compendium on cystic echinococcosis. Brigham Young University, Provo, UT, 1997.

Azab M.E., Bishara S.A., Ramzy R.M., Oteifa N.M., El-Hoseiny L.M. \& AHMED M.A. The evaluation of HLA-DRB1 antigens as susceptibility markers for unilocular cystic echinococcosis in Egyptian patients. Parasitology Research, 2004, 92 (6), 473-477.

Ballingall K.T., Wright H., Redmond J., Dutia B.M., Hopkins J., Lang J., Deverson E.V., Howard J.C., Puri N. \& Haig D. Expression and characterization of ovine major histocompatibility complex class II (OLA-DR) genes. Animal Genetics, 1992, 23, 347-359.

Blattman A.W., Hulme D.J. \& Kinghorn B.P. A search for associations between major histocompatibility complex restriction fragment length polymorphism bands and resistances to Haemonchus contours infection in sheep. Animal Genetics, 1993, 24, 277-282.

Briles W.E., STONE H.A. \& Cole R.K. Marek's disease: effects of B histocompatibility alloalleles in resistant and susceptible chicken lines. Science, 1977, 195, 193-195. 
Dalimi A., Motamedi G., Hosseini M., Mohammadian B., Malaki H., Ghamari Z. \& Ghaffari F.F. Echinococcosis/hydatidosis in western Iran. Vetertinary Parasitology, 2002, 105 (2), 161-171.

Deverson E.V., Wright H., Watson S., Ballingall K., HusKISSON N., Diamond A.G. \& Howard J.C. Class II major histocompatibility complex genes of the sheep. Animal Genetics, 1991, 22, 211-225.

Dukkipati V.S., Blair H.T., Garrick D.J. \& Murray A. OvarMhc- ovine major histocompatibility complex: role in genetic resistance to diseases. New Zealand Veterinary Journal, 2006, 54, 153-160.

Dutia B.M., McConnell I., Ballingall K.T., Keating P. \& Hopkins J. Evidence for the expression of two distinct MHC class II DRB like molecules in the sheep. Animal Genetics, 1994, 25, 235-241.

Eckert J. \& Deplazes P. Biological, epidemiological, and clinical aspects of echinococcosis, a zoonosis of increasing concern. Clinical Microbiology Reviews, 2004, 17 (1), 107-135.

Gottstein B., Bettens F., Parkinson A.J. et aL. Immunological parameters associated with susceptibility or resistance to alveolar hydatid disease in Yupiks/Inupiats. Arctic Medical Research, 1996, 55 (1), 14-19.

Herrmann L.M., Brown W.C., Lewis G.S. \& Knowles D.P. Identification and phylogenetic analysis of $15 \mathrm{MHC}$ Class II DRB1 beta1 expressed alleles in a ewe-lamb flock. Immunogenetics, 2005, 57, 855-863.

Jenkins D.J., Romig T. \& Thompson R.C.A. Emergence reemergence of Echinococcus spp., a global update. International Journal for Parasitology, 2005, 35, 1205-1219.

JIANG W.S. The protection and exploitation of Duolang sheep variety resources in Sinkiang. China Herbivores, 2006, 26 (2), 28-30.

Jugo B.M. \& Vicario A. Lymphocyte antigens in sheep: linkage to the MHC class II DRB1 gene. European Journal of Immunogenetics, 2001, 28, 451-458.

Kaufman J. \& Venugopal K. The importance of MHC for Rous sarcoma virus and Marek's disease virus - Some Payne-ful considerations. Avian Pathology, 1998, 27, S82-S87.

KLEIN J. Natural history of the major histocompatibility complex. Wiley, New York, 1986.

Konnai S., Nagaoka Y., Takesima S., Onuma M. \& Aida Y. Technical note: DNA typing for ovine MHC DRB1 using polymerase chain reaction-restriction fragment length polymorphism (PCR-RFLP). Journal of Dairy Science, 2003, 86, 3362-3365.

Li F., Shi Y., Shi D., Vuitton D.A. \& Craig P.S. HLA-DRB1 allele in 35 patients with alveolar echinococcosis in Gansu Province of China. Chinese Medical Journal (Engl), 2003, 116 (10), 1557-1560.

Li YAN, YAN JIANG-LIN \& Li Jing. Investigation and analysis of epidemic conditions of hydatidosis disease of sheep in Sinkiang. Journal of Shibezi University (Natural Science), China, 2005, 23, 60-64.

Linze P., Hong S., Bin J. ET AL. Polymorphism analysis of MHC-DRB1 gene in Chinese Merino sheep (Sinkiang
JunKen Type) by PCR-RFLP. ActaVeterinaria et Zootechnica Sinica, China, 2007, 38, 1115-1119.

Liu Yunfang, Gao Jianfeng \& Pan Xiaoliang. A study on preparation of DNA from Sheep blood. Journal of Shibezi University (Natural Science), China, 1997, 1, 136-138.

LONGENECKer B.M. \& Gallatin W.M. Genetic control of resistance to Marek's disease. IARC Sci Publ, 1978, 24 (Pt 2), 845-850.

RAUSCH R.L. Life cycle patterns and geographic distribution of Echinococcus species, in: Echinococcus and hydatid disease. Thompson R.C.A. \& Lymbery A.J. (Eds), CAB International, Oxon, 1995.

Sayers G., Good B., Hanrahan J.P. et al. Major histocompatibility complex DRB1 gene: its role in nematode resistance in Suffolk and Texel sheep breeds. Parasitology, 2005, 131 (3), 403-409.

SChierman L.W. \& Coldins W.M. Influence of the major histocompatibility complex on tumor regression and immunity in chickens. Poultry Science, 1987, 66, 812-818.

Schwaiger F.W., Gostomski D., Stear M.J., Duncan J.L., McKellar Q.A., Epplen J.T. \& BuitKamp J. An ovine major histocompatibility complex DRB1 allele is associated with low faecal egg counts following natural, predominantly Ostertagia circumcincta infection. International Journal for Parasitology, 1995, 25, 815-822.

Schwaiger F.W., Maddox J., Ballingall K., Buttkamp J., CraWFORD A.M., Dutia B.M. ET AL. The Ovine Major Histocompatibility Complex, in: The major histocompatibility complex region of domestic animal species. Schook L.B. \& Lamont SJ (Eds), CRC, Florida, 1996, 121-176.

Scott P.C., Maddox J.F., Gogolin-Ewens K.J. \& Brandon M.R. The nucleotide sequence and evolution of ovine MHC class II B genes: DQB and DRB. Immunogenetics, 1991, 34, 80-87.

Shcherbakov A.M. \& Monje-Barredo P.A. The distribution of the HLA antigen system among patients with echinococcosis. Med Parazitol (Mosk), 1989, 6, 75-80.

Sun D.X., Zhang Y. ET AL. Polymorphism of the second exon of MHC-DRB gene in Chinese local sheep and goat. Biochemical Genetics, 2004, 42, 385-390.

Xu A.,Van EijK M.J. \& Park C. Polymorphism in BoLA-DRB3 exon 2 correlated with resistance to persistent lymphocytosis caused by bovine leukemia vires. Journal of Immunology, 1993, 15, 6977-6985.

Xu R.F., LI K. \& Chen G.H. Detection the neomorph and polymorphism of MHC II in chicken. ActaVeterinaria et Zootechnica Sinica, China, 2005, 36, 1247-1256.

Yang Yi, Xu Jin-rui \& Wang Jie. Polymorphisms of Gola DRB3 exon 2 in four populations of sichuan local goats. Heilongjiang Animal Science And Veterinary Medicine, China, 2006, 1, 12-15.

Received on May $25^{\text {th }}, 2010$ Accepted on October $29^{\text {th }}, 2010$ 